\title{
GROUNDWATER QUALITY OF THE AG. PARASKEVI/TEMPI VALLEY KARSTIC SPRINGS - APPLICATION OF A TRACING TEST FOR RESEARCH OF THE MICROBIAL POLLUTIO (KATO OLYMPOS/NE THESSALY)
}

\author{
Stamatis G. \\ Agricultural University of Athens, Institute of Mineralogy-Geology, Iera Odos 75, GR-118 55 Athens, \\ stamatis@aua.gr .
}

\begin{abstract}
The study of the Kato Olympos karst system, based on the implementation of tracer tests and hydrochemical analyses, is aimed at the investigation of surface-groundwater interaction, the delineation of the catchment area and the detection of the surface microbial source contamination of the Tempi karst springs. The study area is formed by intensively karstified carbonate rocks, metamorphic formations, Neogene sediments and Quaternary deposits. The significant karst aquifer discharges through karst springs in Tempi valley and in Pinios riverbed. The karst springs present important seasonal fluctuations in discharge rate, moderate mineralization with TDS between 562 to $630 \mathrm{mg} / \mathrm{l}$ and they belong to $\mathrm{Ca}-\mathrm{HCO}_{3}$ water type. The inorganic pollution indicators, such as $\mathrm{Na}^{+}, \mathrm{K}^{+}, \mathrm{Cl}, \mathrm{NO}_{3}^{-}$ , $\mathrm{NH}_{4}{ }^{+}, \mathrm{PO}_{4}{ }^{3}$, show low concentrations and do not reveal any surface influences. On the other hand, the presence of microbial parameters in karst springs proclaims the high rate of microbial contamination of karst aquifer. Tracer tests reveal hydraulic connection between the surface waters of Xirorema-Rapsani basin and the karst aquifer. The high values of groundwater flow velocity upwards of $200 \mathrm{~m} / \mathrm{h}$, show the good karstification rate of the carbonate formations and the cavy structure dominated in the study area, as well as the low self purification capability of the karst aquifer.
\end{abstract}

Key words: Hydrochemistry, microbiological analyses, tracer test, karst aquifer, Kato Olympos, NEThessaly-Greece.

\section{Introduction}

In many regions the karst systems are parts of the bare karst and are characterized by the absence of soil cover, which contributes to the filtration of the infiltrated surface waters. Karst aquifers are also characterized by great fluctuations in water levels, high flow velocities, short residence times and fast hydraulic reactions to hydrologic events. Thus, karst aquifers are particularly vulnerable to chemical and microbial contamination. Therefore, karst groundwater needs special protection. The major part of the study area is formed by intensively fractured and karstified carbonate formations, in that a significant aquifer is developed. The karst aquifer discharges through riparian karst springs in Tempi valley as well as in Pinios riverbed. The most important spring is Agia Paraskevi spring with high discharge rate $(>1000 \mathrm{l} / \mathrm{s})$. All karst springs present good water quality regarding the inorganic chemical load. On the contrary the intense presence of microbial parameters proclaims the microbial contamination of the karst aquifer. This significant karst aquifer of the study area remains up today 
unexploited and the karst waters flow into Pinios River. In future this large amount of karst water could contribute positively in the increasing demand for drinking water, after suitable treatment, or for irrigation use or for artificial recharge in the aquifers situated in delta plain of Pinios River. This study deals with the Kato Olympos karst system using hydrochemical and tracer methods. The main goal of the study is the investigation of the groundwater quality and the hydraulic connection between surface- and karst water, the delineation of the catchment area as well as the detection of the surface microbial source contamination of the karst springs. The cost of this study is reimbursed from the Laboratory of Mineralogy and Geology of the Agriculture University of Athens.

\section{Geological setting}

The study area covers the south part of Kato Olympos Mountain at East Thessaly (Fig. 1), with the valley of Tempi spreading out at its southeastern edge. The direction of the valley is SW-NE and it is crossed by Pinios River, which drains Thessaly plain and falls into Aegean Sea. The major part of the valley is composed by carbonate formations of the Olympos - Ossa Unit, which also explains the general geomorphological situation of the broad area. Due to the tectonic structure of the area, the carbonate rocks outcrop at the central part, while the metamorphic formations, which belong to the overthrusted units, occur at the fridge of the study area. The carbonate and metamorphic formations define the bare and covered karst system of Kato Olympos respectively. Limestones are fractured and extremely karstified. Profound karstic landforms like dolines, swallow holes, dry valleys and canyons, can be remarked on the limestones surface, which reveal the development of the exoand endokarstic processes in the area.

The mountain of Kato Olympos is formed by pre-alpine and alpine formations, which belong to a) Olympos-Ossa-, b) Ampelakia- and c) Pelagonian-Units. At the northeastern part of the basin the preapline and apline formations are overlaid by post-alpine lacustrine and continental deposits of Neogene-Quaternary age (Fig. 1). Olympos - Ossa Unit is considered to be autochthonous to parautochthonous at least and it is regarded as a tectonic window, being older than the metamorphic formations of Ampelakia- and Pelagonian-Units. Kato Olympos Massif forms an anticlinorium with NNE main direction axis. Primary cross structures of NNE and secondary ones of E-W direction are also presented (Katsikatsos et al., 1980, Jacobshagen, 1986). This geotectonic Unit consists of a series of crystalline limestones and dolomites up to $1000 \mathrm{~m}$ visible thickness, overlaid normally by meta-flysch rocks such as phyllites, schists and schist-sandstones with intercalations of thin (20$50 \mathrm{~m}$ ) sandy crystalline limestone. The formations of Ampelakia Unit (Blueschist Unit) are widely distributed in the south-western part of the area and their thickness exceeds locally $500 \mathrm{~m}$ (Katsikatsos et al., 1980). These formations consist of sedimentary rocks (meta-pelites and metagreywackes) with intercalations of meta-basites and marbles. In general, these rocks are intensively fractured, folded and alterated.

The Pelagonian-Unit includes metamorphic formations such as a) gneiss and gneiss-schists of Palaeozoic age up to $600 \mathrm{~m}$ thick, b) schists, gneiss schists and amphibolites with marble and sipolines alternations of neo-Palaeozoic to middle-Triassic age up to $600 \mathrm{~m}$ thick and c) metamorphic basic ophiolitic rocks, amphibolites, prasinites and serpentinites of the Pre-upper Cretaceous tectonic cover with a total thickness reaching $500 \mathrm{~m}$ as well as of upper Cretaceous marbles up to $200 \mathrm{~m}$ thick. These rocks occupy a significant part of Kato Olympos and are formed in the north-eastern as well as south-western part of the study area. The Neogene formations consist of conglomerates, marls and silts, outcropped mainly in the eastern part of the study area, where are widely exposed and their thickness exceeds $300 \mathrm{~m}$. The Pleistocene sediments are represented by old debris cone and collu- 


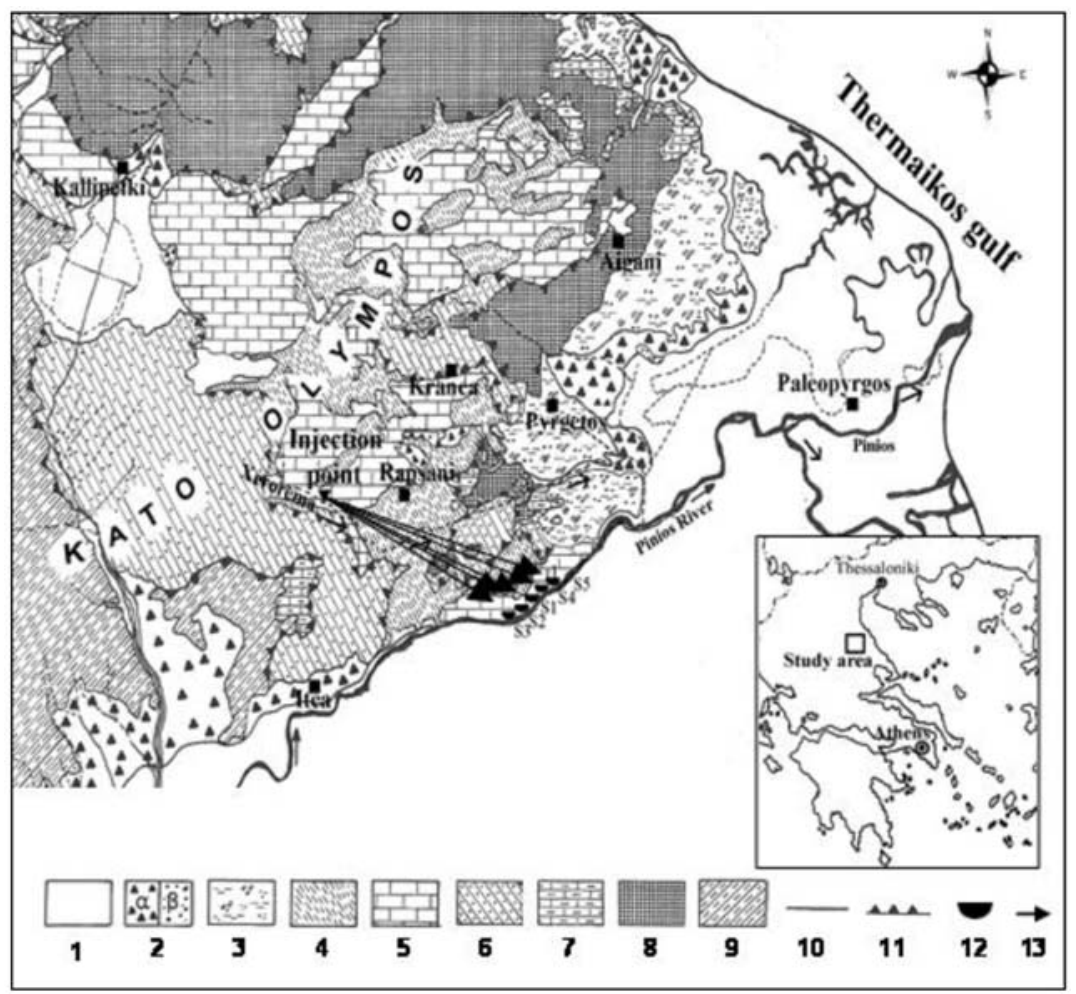

Fig. 1: A simplified geological map of the study area (Katsikatsos et al. 1987) (1: Alluvial deposits (Holocene); 2: Old talus cones $(\alpha)$ and Fluvio-lacustrine deposits $(\beta)$ (Pleistocene); 3: Terrestrial and lacustrine deposits (Neogene); 4: Flysch epizonally metamorphic (M. Eocene); 5: Crystalline limestones (Jurassic-M. Eocene); 6: Blue schists, gneiss-schists, gneisses and prasinites; 7: Marbles (M.-U. Jurassic-U. Cretaceus); 8: Metamorphic basic ophiolitic rocks (Preuppercretaceus tectonic nappe); 9: Gneisses, gneiss-schists and amphibolites (Precarboniferous-M. Triassic); 10: Geological boundary; 11: Overthrust; 12: Monitoring carstic springs S1-S5; 13: Presence of the tracer).

vial deposits, as well as by terrace and basin deposits. The Holocene deposits are developed in Pinios delta area. They consist of loose materials such as silts, red-clays and sands with low participation of coarse clusters (Godfriaux, 1968, Katsikatsos, 1992).

\section{Hydrogeology}

The hydrogeological conditions of the study area depend directly on the presence of carbonate rocks and the predominant tectonic structures. An important karst aquifer is formed into the crystalline limestones and dolomites of Olympos - Ossa Unit. It is considered that significant quantities of the karst water flow towards E and fall into Pinios delta plain as well as into Thermaikos Gulf through fractured zones. Part of this water seeps through shear zones of metamorphic rocks to the eastern and western slopes. Significant quantities of the karst water seeking outlets at the lower topographic positions in Tempi valley form characteristic karst springs with high discharge rates near or into the riverbed of Pinios. 
Depending on their discharge the most important springs are S1 (Agia Paraskevi) with discharge rate from 400 upwards to 1000 1/s, S2 from 2 to 150 1/s, S3 with discharge rate between 1 and 60 1/s, S4 from 5 to 200 1/s and S5 from 10 to 250 1/s (Fig. 1). The discharge rates of these springs are significantly high especially during the wet period, when they exceed 100 1/s. Table 1 shows the discharge rates and the chemical parameters of the springs during the investigation period of this study. An aquifer of limited importance is formed in metamorphic rocks such as phyllites, schists, gneisses, amphibolites and meta-flysch. Locally, where the effective porosity due to lithology and fractured tectonic increases significantly, low discharge springs are occurred. The springs with discharge rates lower than $1 \mathrm{l} / \mathrm{s}$, are caused by the presence of metasand and crystallized carbonate horizons in the meta-flysch formations. In the middle and upper part of the Blueschist formations of AmpelakiaUnit, a limited number of springs with lower than $0,5 \mathrm{l} / \mathrm{s}$ discharge rate are developed. In these formations, the increase of secondary porosity due to lithology and tectonic structure can be observed.

The major part of the northeastern area is formed by ultrabasic massifs (ophiolites, serpentinites). In the synclinal structures of these formations an aquifer of local importance is formed and feeds some springs with low discharge rates, ranging between 0,1 and $2,5 \mathrm{l} / \mathrm{s}$. According to their geomorphological position and the flow direction, the spring water infiltrates underground and recharges the underlying carbonate massif.

\section{Material and Methods}

Hydrochemical analyses: Sampling of karst springs S1, S2, S3, S4, S5 and of surface water in Xirorema basin took place on 3.1.2007 aiming at the investigation of the hydrochemical character of the springs. The criterion for the sampling was the discharge rate of every spring. For the rest of the karst springs all physicochemical parameters were measured in situ. Portable devises were used in order to measure the physicochemical parameters, such as $\mathrm{T}{ }^{\circ} \mathrm{C}$ and electrical conductivity EC (WTW/LF-330), pH value (WTW/330i), dissolved oxygen DO (WTW/OXI-96) and the discharge Q 1/s (Flow Probe FP101/Global Water). In the laboratory of Mineralogy-Geology Section of the Agriculture University of Athens with the use of titration methods, spectral photometer (HACK, $\mathrm{DR} / 3000$ ), flame photometer (INTECH/420) and atom absorption spectrometer (GBC/908/AA) the parameters, Hardness, $\mathrm{Ca}^{2+}, \mathrm{Mg}^{2+}, \mathrm{Na}^{+}, \mathrm{K}^{+}, \mathrm{HCO}_{3}^{-}, \mathrm{Cl}^{-}, \mathrm{SO}_{4}^{2-}, \mathrm{NO}_{3}^{-}, \mathrm{NO}_{2}{ }^{-}, \mathrm{NH}_{4}^{+}, \mathrm{PO}_{4}{ }^{3-}, \mathrm{SiO}_{2}$, $\mathrm{KMnO}_{4}$, Fetot, $\mathrm{Mn}^{2+}, \mathrm{Cu}^{2+}, \mathrm{Ni}^{2+}, \mathrm{Zn}^{2+}$ were detected. The microbiological analyses were conducted in the Laboratory of Chemical Analyses, DEYA-Larisa.

Tracer Tests: On 3.1.2007 tracer tests took place in the basin of Xirorema, western from Rapsani town, at the Milos - Stalagmatia location, where a shallow hole is occurred and total infiltration of surface water can be observed. The quantity of $3 \mathrm{~kg}$ Uranine dye was used. The dye was dissolved in approximately $50 \mathrm{lt}$ plastic bottles of water. At 11:00 the solution was injected into the shallow-hole. Samples were taken every one - two hours from three karst springs with high discharge rates in Tempi valley (S1:2400 1/s, S2:120 1/s and S5:235 l/s) in order to check the appearance of the dye. In the rest of the karst springs qualitative controls took place using charcoal bags. In every outflow point $10 \mathrm{gr}$. charcoal bags were installed. In the Laboratory the dye was flushed from the charcoal bags with the use of ethyl alcohol. The Uranine dye was detected in the flushing solution. The sampling began on 3.1.2007, at 18:00 and finished on 7.1.07 at 22:00. The goal of this experiment was to determine the interaction between the surface waters of Xirorema basin and the karst groundwater as well as to detect the surface microbial source contamination of the karst springs. In all 245 water samples were taken. The water samples were collected into $50 \mathrm{ml}$ polythene plastic vials, and maintained in darkness until their analysis. The detection of the Uranine dye took place in the laboratory of Hydrogeology Section of IGME - Athens with the use of the PERKIN/ELMER LS3 Spectrofluorometer. 
Table 1.

\begin{tabular}{|c|c|c|c|c|c|c|}
\hline Sampling points & $\begin{array}{c}\text { S1 } \\
\text { (Ag. Paraskevi) }\end{array}$ & $\begin{array}{c}\text { S2 } \\
\text { (Xenonas) }\end{array}$ & $\begin{array}{c}\text { S3 } \\
\text { (Platanos) }\end{array}$ & $\begin{array}{c}\mathrm{S} 4 \\
\text { (Restorant) }\end{array}$ & $\begin{array}{c}\text { S5 } \\
\text { (Phylakio OSE) }\end{array}$ & Xyrorema \\
\hline Discharge 1/s & 2430 & 120 & 15 & 25 & 235 & 42 \\
\hline Temperature ${ }^{\circ} \mathrm{C}$ & 14.5 & 14.2 & 14,5 & 14.2 & 14.6 & 4,5 \\
\hline El. Cond. $\mu S / \mathrm{cm}$ & 671 & 685 & 640 & 695 & 581 & 98 \\
\hline $\mathrm{pH}$ & 6.8 & 7.1 & 6.9 & 7.1 & 6.9 & 7.1 \\
\hline $\mathrm{O}_{2} \mathrm{mg} / \mathrm{l}$ & 8.9 & 9.4 & 9,6 & 9.8 & 9.6 & 10.2 \\
\hline $\mathrm{KMnO}_{4} \mathrm{mg} / \mathrm{l}$ & 2.6 & 4.6 & 4.6 & 4.5 & 4.6 & 9.8 \\
\hline TDS mg/l & 630 & 608 & 593 & 620 & 562 & 112 \\
\hline \multicolumn{7}{|l|}{ Hardness } \\
\hline Total ${ }^{\circ} \mathrm{dH}$ & 21.8 & 21.0 & 19,8 & 25.8 & 18.8 & 3.3 \\
\hline Temporal " & 21.0 & 20.1 & 19,6 & 23.8 & 18.4 & 3.0 \\
\hline Permanent " & 0.8 & 0.9 & 0,2 & 2.0 & 0.4 & 0.3 \\
\hline \multicolumn{7}{|l|}{ Main Elements } \\
\hline $\mathrm{Ca}^{2+} \quad \mathrm{mg} / \mathrm{l}$ & 113.6 & 114.6 & 108,8 & 115.2 & 102.1 & 18.2 \\
\hline $\mathrm{Mg}^{2+} \quad "$ & 25.6 & 21.8 & 20,4 & 23.8 & 20.2 & 3.5 \\
\hline & 8.5 & 5.6 & 6,9 & 6.6 & 5.1 & 3.5 \\
\hline $\mathrm{K}^{+}$ & 0.9 & 1.2 & 0,9 & 0.8 & 0.8 & 0.4 \\
\hline $\mathrm{NH}_{4}^{+}$ & 0.028 & 0.032 & 0,024 & 0.032 & 0.026 & 0.036 \\
\hline $\mathrm{HCO}_{3-}^{-}$ & 457.5 & 439.2 & 427,1 & 451.4 & 402.6 & 67.1 \\
\hline $\mathrm{Cl}^{-}$ & 14.2 & 10.6 & 14.2 & 10.6 & 14.2 & 4.6 \\
\hline $\mathrm{SO}_{4}^{2-}$ & 0.5 & 6.2 & 7,1 & 2.8 & 8.1 & 6.4 \\
\hline $\mathrm{NO}_{3}^{-}$ & 3.2 & 1.8 & 1,2 & 2.0 & 1.2 & 4.5 \\
\hline $\mathrm{PO}_{4}^{3-}$ & 0.15 & 0.22 & 0,12 & 0.26 & 0.12 & 0.28 \\
\hline $\mathrm{SiO}_{2}$ & 5.8 & 6.2 & 6.4 & 6.0 & 7.4 & 2.5 \\
\hline \multicolumn{7}{|l|}{ Tracer Elements } \\
\hline $\mathrm{Fe}_{\mathrm{tot}} \quad \mathrm{ppm}$ & 0.001 & 0.003 & 0,002 & 0.003 & 0.004 & $<0.001$ \\
\hline $\mathrm{Mn}^{2+}$ & 0.022 & 0.018 & 0,028 & 0.024 & 0.025 & $<0.001$ \\
\hline $\mathrm{Cu}^{2+}$ & 0.006 & 0.008 & 0,008 & 0.004 & 0.002 & $<0.001$ \\
\hline $\mathrm{Ni}^{2+}$ & 0.001 & 0.001 & 0,001 & 0.001 & 0.001 & $<0.001$ \\
\hline $\mathrm{Zn}^{2+}$ & 0.001 & 0.001 & 0,001 & 0.001 & 0.001 & $<0.001$ \\
\hline
\end{tabular}

\section{Results of chemical analyses}

Table 1 shows the results of chemical analyses. Agia Paraskevi spring (S1) presents the highest discharge rate (2430 1/s) among all other water manifestations (15-235 1/s) in this part of Pinios River basin. All karst springs show almost identical chemical character with negligible differences. 
This hydrochemical similarity indicates that the karst springs discharge from the same groundwater body. The temperature ranges between $14,2{ }^{\circ} \mathrm{C}$ and $14,6{ }^{\circ} \mathrm{C}$, the $\mathrm{pH}$ value between 6,8 and 7,1 and the electrical conductivity from 581 to $695 \mu \mathrm{S} / \mathrm{cm}$. All spring waters are almost saturated in $\mathrm{O}_{2}$ $(8,9-9,8 \mathrm{mg} / \mathrm{l})$. The TDS value ranges from 562 to $630 \mathrm{mg} / \mathrm{l}$. Regarding their chemical character the karst groundwaters and the surface water of Xirorema belong to the hydrochemical type of Ca$\mathrm{HCO}_{3}$. The total hardness ranges from 18,8 and $25,8^{\circ} \mathrm{dH}$, thus the waters are hard waters $\left(18-30{ }^{\circ} \mathrm{dH}\right)$ (Matthess 1973). $\mathrm{Ca}^{2+}(102,1-115,2 \mathrm{mg} / \mathrm{l})$ and $\mathrm{Mg}^{2+}(20,2-25,6 \mathrm{mg} / \mathrm{l})$ are the dominant cations, while $\mathrm{Na}^{+}$and $\mathrm{K}^{+}$show low concentrations. $\mathrm{HCO}_{3}{ }^{-}(402,6-457,5 \mathrm{mg} / \mathrm{l})$ is the dominant anion, while all the other anions present low concentrations $\left(\mathrm{Cl}^{-}: 10,6-14,2 \mathrm{mg} / 1, \mathrm{SO}_{4}{ }^{2-:}: 0,5-8,1 \mathrm{mg} / 1, \mathrm{NO}_{3}{ }^{-}: 1,2-3,2 \mathrm{mg} / \mathrm{l}\right.$, $\left.\mathrm{NH}_{4}{ }^{+}: 0,024-0,032 \mathrm{mg} / 1, \mathrm{PO}_{4}{ }^{3--}: 0,12-0,26 \mathrm{mg} / \mathrm{l}\right)$. In all spring waters the absence of inorganic pollution is noticeable (low concentrations of $\mathrm{NO}_{3}{ }^{-}, \mathrm{NH}_{4}{ }^{+}$and $\mathrm{PO}_{4}{ }^{3-}$ ). The $\mathrm{KMnO}_{4}$ values are also low $(2,6-4,6 \mathrm{mg} / \mathrm{l})$, revealing that the presence of organic compounds are insignificant. The trace elements concentrations $\mathrm{Fe}_{\mathrm{tot}}, \mathrm{Cu}^{2+}, \mathrm{Ni}^{2+} x \alpha \mathrm{l} \mathrm{Zn}^{2+}$ are at the limit of detection, with exception of $\mathrm{Mn}^{2+}: 0,018$ $0,028 \mathrm{ppm}$. Generally the karst waters of Tempi valley show good water quality regarding their chemical parameters, which are in low levels and under the upper permissible limits according to the European Directive 99/83 EU for drinking water quality.

\section{Microbial contamination of karst aquifer}

The microbiological analyses, which took place (6.11.2006) in water sample from Agia Paraskevi (S1) spring have shown the microbial contamination of the karst aquifer. In table 2 the results of the microbiological analyses are presented. As it is shown, many of the microbiological parameters are found in high levels, which means that the karst water is unsuitable for drinking water supply without further treatment. Surface waters which are contaminated by human activity, sink underground and endanger the groundwater quality. This microbial contamination could be caused, because there are many sheepcotes in the area especially very close to Xirorema stream. The sewages from septic tanks of Rapsani settlement could also contribute to this microbial contamination of the karst spring, although Rapsani is built on meta-flysch formations (Fig. 1).

The microbial and the inorganic chemical load is transported via Xirorema stream in the shallowhole and after few hours has already reached the karst aquifer. The limited self - purification capability of the karst aquifer and the high flow velocities allow the appearance of the microbial parameters in the karst springs. These conditions are encouraged particularly at the wet period, where obviously the animal wastes will increase considerably.

Table 2.

\begin{tabular}{|l|c|c|}
\hline Microbial Parameters & Spring S1 & $98 / 83 \mathrm{EE}$ \\
\hline Total Coliforms & $10-240$ & $0 / 100 \mathrm{ml}$ \\
\hline Fecal Coliforms & $0-50$ & $0 / 100 \mathrm{ml}$ \\
\hline Escherichia Coli & $0-50$ & $0 / 250 \mathrm{ml}$ \\
\hline Enterokokkes & $0-41$ & $0 / 250 \mathrm{ml}$ \\
\hline Bacteria colony $/ \mathrm{ml}$ water at $37^{\circ} \mathrm{C} / 48 \mathrm{~h}$ & $0-3$ & $20 / 1 \mathrm{ml}$ \\
\hline Bacteria colony $/ \mathrm{ml}$ water at $22^{\circ} \mathrm{C} / 72 \mathrm{~h}$ & $0-4$ & $100 / 1 \mathrm{ml}$ \\
\hline Pseudomonas & 0 & $0 / 250 \mathrm{ml}$ \\
\hline
\end{tabular}




\section{Tracer Test in karst springs}

Within the frame of this study, tracer tests took place in order to investigate the hydraulic connection between the surface waters of Xirorema basin and the karst groundwaters and to evaluate the impact of the microbial hazard on Tempi karst springs. The injection point was a shallow hole located in the above mentioned basin (Fig. 1). During the investigation period a total infiltration of surface water was observed. The day, when tracer tests took place, the surface runoff of Xirorema stream was measured in 42 1/s. The Uranine dye was detected in all karst springs. In S1, S2 and S5 springs the dye was detected after sampling and chemical analysis, while in the rest of the springs after flush of the charcoal bags with ethyl alcohol.

Figure 2 demonstrates the breakthrough curve for Uranine in S1 spring with the representative times after injection ( $\mathrm{t} 1$ : time of first appearance of Uranine, $\mathrm{t} 2$ : passage time of maximum concentration, $\mathrm{t} 3$ : passage time of $50 \%$ of the recovered Uranine amount in the sampling point and $\mathrm{t} 4$ : Last appearance of the dye). The curve of recovered Uranine is also depicted in figure 2. The breakthrough curve for Uranine has, except the peak of the maximum concentration, other three characteristic peaks with high dye concentrations. Their appearance has to do with the snow melting and the increase in surface runoff, which has probably flushed the dye from the karstic conduits in the karst system.

This type of curve (steep and narrow) is characteristic for intensively karstified systems (Mull et al. 1988; Käss 1992; Wernli 2003). The cavy conditions, which dominate in the middle part between the injection point and the Agia Paraskevi spring of Tempi, were confirmed after the discovery of a cave from a speleologist team at the I.M Agion Theodoron location, south from Rapsani (Fig. 1). Two characteristically photos from this cave are shown in figure 3 . The photos depict the karstification rate of the carbonate formations.

In table 3 the results of the second tracer test are presented. The maximal flow velocity $\left(\mathrm{V}_{\max }\right)$, which is taken as the velocity that corresponds to the first appearance of the tracer, ranges from $258 \mathrm{~m} / \mathrm{h}$

Table 3.

\begin{tabular}{|c|c|c|c|c|c|}
\hline Monitoring springs & & S1 & S3 & S5 & Mean value \\
\hline Elevation & (m) & 10 & 11 & 10 & 10,3 \\
\hline Total distance from Injection point & (m) & 6.030 & 5.929 & 6.180 & 6.046 \\
\hline \multirow{2}{*}{ Initial arrival of Uranine dye } & (h) & 23 & 23 & 23 & 23 \\
\hline & $\mathrm{V}_{\max }(\mathrm{m} / \mathrm{h})$ & 262 & 258 & 269 & 263 \\
\hline \multirow{2}{*}{ Maximal concentration } & $\begin{array}{ll}\mathrm{t}_{2} & (\mathrm{~h})\end{array}$ & 27 & 27 & 27 & 27 \\
\hline & $\mathrm{V}_{\text {Cmax }}(\mathrm{m} / \mathrm{h})$ & 223 & 220 & 229 & 224 \\
\hline \multirow{2}{*}{ Discharge of $50 \%$ conc. Uranine dye } & $\mathrm{t}_{3} \quad(\mathrm{~h})$ & 30 & 28 & 33 & 30 \\
\hline & $\mathrm{V}_{\mathrm{a}} \quad(\mathrm{m} / \mathrm{h})$ & 201 & 212 & 188 & 200 \\
\hline \multirow{2}{*}{ Last appearance } & $\mathrm{t}_{4} \quad(\mathrm{~h})$ & 101 & 93 & 105 & 100 \\
\hline & $\mathrm{V}_{\min }(\mathrm{m} / \mathrm{h})$ & 60 & 64 & 59 & 61 \\
\hline Discharge duration of Uranine dye & $\mathrm{t}_{1}-\mathrm{t}_{4} \quad(\mathrm{~h})$ & 78 & 70 & 82 & 77 \\
\hline Residence time & $\mathrm{t}_{0}-\mathrm{t}_{4} \quad(\mathrm{~h})$ & 101 & 93 & 105 & 100 \\
\hline \multirow{2}{*}{ Total recovery Uranine } & \multirow{2}{*}{ Conc. (gr) } & 7,93 & 1,14 & 0,87 & \multirow{2}{*}{ - } \\
\hline & & \multicolumn{3}{|c|}{$\Sigma=9,94 \mathrm{gr}=0,33 \%$} & \\
\hline
\end{tabular}




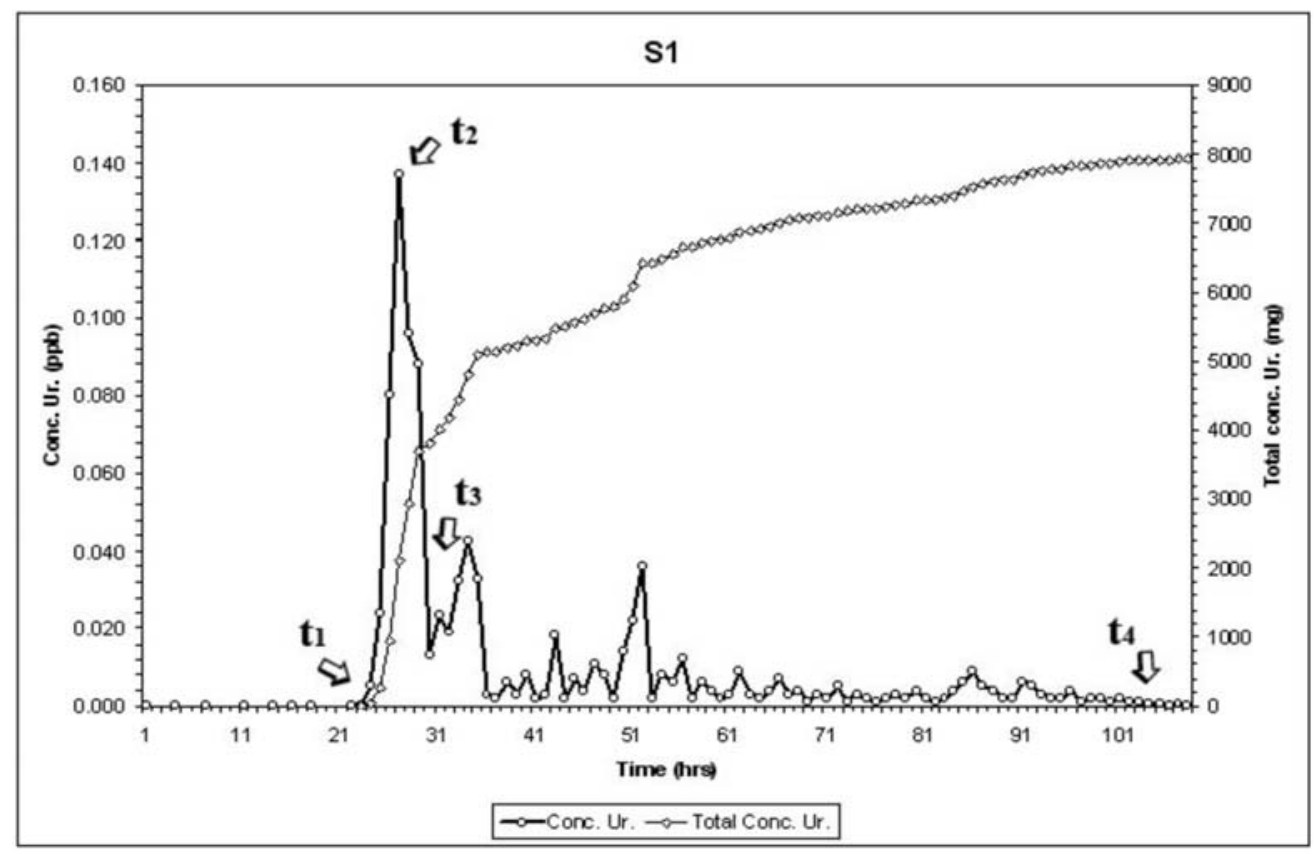

Fig. 2: Breakthrough curve for Uranine, $\mathrm{S} 1$ spring (Ag. Paraskevi) and the respective cast line (t1: time of first appearance of Uranine, $\mathrm{t} 2$ : passage time of maximum concentration, $\mathrm{t} 3$ : passage time of $50 \%$ of the Uranine in the sampling point and t4: Last appearance of the dye).
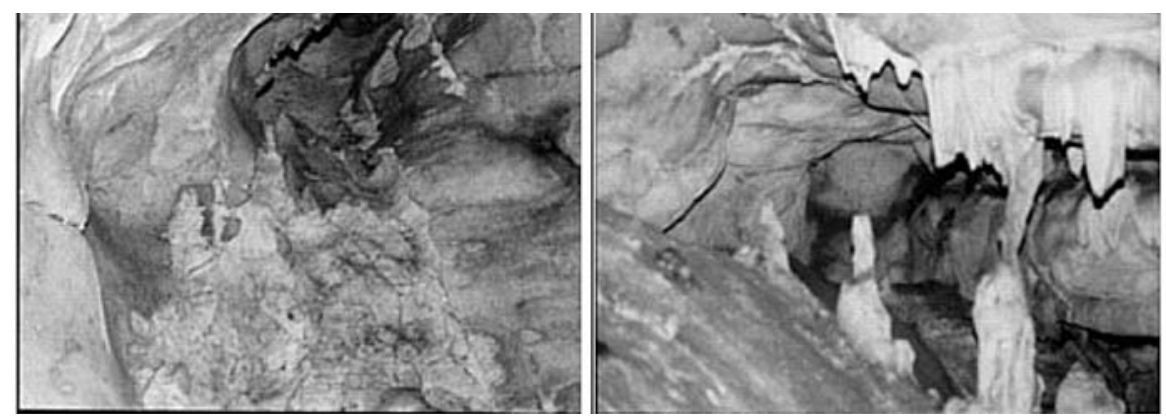

Fig. 3: Characteristic photos from the Routsi/Rapsani cave near I. M. Ag. Theodoron location (Fotos Ath. Argyroulis) (www.rapsani.com).

to $269 \mathrm{~m} / \mathrm{h}$. The dominant velocity $\left(\mathrm{V}_{\mathrm{Cmax}}\right)$, which is defined as the time that corresponds to the passage time of the maximal concentration, ranges from $220 \mathrm{~m} / \mathrm{h}$ to $229 \mathrm{~m} / \mathrm{h}$. Furthermore, the mean flow velocity $\mathrm{V}_{\mathrm{a}}$, which corresponds to the time in the breakthrough curve, at which $50 \%$ of the recovered tracer amount has passed the sampling point, varies between $188 \mathrm{~m} / \mathrm{h}$ and $212 \mathrm{~m} / \mathrm{h}$. The mean value of the flow velocities is $229 \mathrm{~m} / \mathrm{h}$.

The recovered Uranine amount at the sampling springs was $9,94 \mathrm{gr}$, that represents $0,33 \%$ of the total injected amount of Uranine, which was $3 \mathrm{Kg}$. This low amount of the recovered dye, could be probably explained, because of the existence of other karst springs into the riverbed or at not ac- 
cessible locations at the north-eastern part of the Pinios River basin. Another explanation could be that an amount of the dye was trapped in the fissures of the karst system. Generally the flow velocities of the karst aquifer is very high due to the intensively karstification. Tracer tests in karst system of Ossa Mountain has shown similar flow velocities (Stamatis and Zagana 2004). The values of the flow velocities of the Kato Olympos karst system and of the Olympos karst System are comparable with the values of the flow velocities derived from tracer tests in karst systems of east Peloponnesus (Morfis and Zojer 1986).

\section{Conclusions}

The hydrogeological study took place in the karst system of Kato Olympos based on the implementation of tracer tests and hydrochemical methods, gave follow results:

- The karst aquifer discharges in karst springs, which emerge in Tempi valley. Another significant amount of the karst water discharges within the riverbed of Pinios River and another one in river's deltaic plain as well as into Thermaikos Golf. The groundwater flow direction trend $\mathrm{S}-\mathrm{SE}$ and is defined from the tectonic structure as well as from the fractured zones, which characterize the study area.

- The karst water flow velocities present high values $\left(\mathrm{V}_{\mathrm{a}}: 188-212 \mathrm{~m} / \mathrm{h}\right)$, revealing the intensively karstification rate of the carbonate formations and probably the cavy conditions dominate in the area.

- The Tempi karst springs, which are fed from the carbonate massif of Kato Olympos show moderate TDS (562-630 mg/l), slightly acid to slightly basic character, relatively high total hardness and belong to $\mathrm{Ca}-\mathrm{HCO}_{3}$ hydrochemical type.

- The inorganic pollution indicators, such as $\mathrm{Na}^{+}, \mathrm{K}^{+}, \mathrm{Cl}^{-}, \mathrm{NO}_{3}{ }^{-}, \mathrm{NH}_{4}{ }^{+}, \mathrm{PO}_{4}{ }^{3-}$ present low concentrations and do not reveal any surface influences. On the other hand, the presence of microbial parameters in karst springs proclaims the high rate of microbial contamination of karst aquifer, which has to do with the existence of sheepcotes and the settlement of Rapsani in the catchment area of the springs. This shows also the low self - purification capability of the karst system. The karst water could be suitable for drinking water supply after further treatment.

\section{Acknowledgments}

I would like to thank the Hydrogeology Section of IGME (Institute of Geology and Mineral Exploration) in Athens for the use of Spectrofluorometer and especially Mrs. Asimina Vitoriou-Georgouli, Hydrogeologist in IGME for her help in the Laboratory work for the detection of the Uranine dye in the water samples. Also, Dr. S. Beltsos (DEYA-Larisa) for conducting the microbiological analyses.

\section{References}

Jacobshagen V. 1986. Geologie von Griechenland. Borntraeger, Berlin-Stuttgart, 363 pp.

Godfriaux I., 1968. Etude geologique de la region de l' Olympe (Grece). -Ann. Geol. Pays Hellen., 19, $1-283$.

Katsikatsos G., Migiros G. and Papazeti E. 1980. Geological map of Greece, 1:50.000, Rapsani sheet. IGME, Athens.

Käss W. 1972. Zweite Internationale Fachtagung zur Untersuchung unterirdischer Wasserwege mittels künstlicher und natürlicher Markierungsmittel, Freiburg i. Br. 1970. - Geol. Jb., C2:382 S., Hannover. 
Käss W. 1992. Geohydrologische Markierungstechnik. Band 9 Lehrbuch der Hydrogeologie, Herausgeber G. Matthess, Borntraeger, Berlin-Stuttgart.

Matthess G. 1973. Die Beschaffenheit des Grundwassers. Borntraeger, Berlin-Stuttgart, 324 pp.

Morfis A. and Zojer, H. 1986. Karst Hydrogeology of the Central and Eastern Peloponnesus (Greece). 5th International Symposium on Underground Water Tracing, Athens, 1986. - Steir. Beitr. Hydrogeologie, B.37/38: 301 S., Graz.

Mull D. S., Liedermann T.D., Smoot J.L., Woosley L.H. 1988. Application of day-tracing techniques for determining solute-transport characteristics of ground water in karst terranes. U.S. Environmental Protection Agency, pp 117.

Stamatis G. and Zagana E. 2004. Application of tracer and hydrochemical methods on the karst system of N. Ossa mountain (NE Thessaly, Greece).- 10 ${ }^{\text {th }}$ Int. conf. of Geol. Soc. Greece, Bull. Geol. Soc. of Greece, XXXVI/4, 2067-2076.

Wernli H. R. 2003. Einfuerung in die Tracerhydrologie. Geograph. Inst. Uni Bern, pp 120. 